\title{
Oxidation of mudstone in a tunnel (Tournemire, France): consequences for the mineralogy and crystal chemistry of clay minerals
}

\author{
D. CHARPENTIER*, R. MOSSER-RUCK, M. CATHELINEAU \\ AND D. GUILLAUME \\ CNRS-UMR 7566 G2R, Université Henri Poincaré, BP 239, 54506 Vandœuvre les Nancy, France
}

(Received 30 September 2002; revised 5 December 2003)

\begin{abstract}
The excavation of a tunnel through a mudstone formation provides an opportunity to examine the effects of the modification of the physical and chemical environment on the rock. The mineralogical and chemical consequences of hydration-dehydration cycles and of oxidation have been evaluated in the case of the Toarcian mudstone formation at the Tournemire experimental site (France). Studies by X-ray diffraction and tansmission electron microscopy of both altered and preserved samples show that the introduction of air and condensed water causes the oxidation of pyrite and the subsequent generation of acid and sulphate-rich waters at the micron scale, in the local environment of pyrites. The fluid-clay particle interactions around the oxidized pyrites induce: (1) a statistical enrichment in $\mathrm{Si}$ of the I-S clay minerals; (2) an increase in the $\mathrm{Fe}(\mathrm{III}) / \mathrm{Fe}$ total ratio in some of the I-S particles; and (3) the dissolution of illite layers in mixed-layer I-S. These evolutions are consistent with the results of numerical modelling which reproduced the interaction between the clay particles and the acid water.
\end{abstract}

KEYwORDS: mudstone, oxidation, mineralogy, crystal chemistry, numerical modelling.

Argillaceous formations have been selected in several countries (e.g. Belgium, Switzerland, France) as potential geological hosts for deep disposal of nuclear waste (Brookins, 1984; Madsen, 1998). Clay minerals have a large sorption capacity, and the low permeability and diffusivity of clay-rich rocks reduce water movement (Lalieux et al., 1996). Moreover, the swelling capacity of some clay particles will cause sealing of potential fractures, and thus significant retardation in the transport of most radionuclides (Higgo, 1987).

The mechanical excavation of any underground materials leads to modifications of the physical and

* E-mail: Delphine.Charpentier@g2r.uhp-nancy.fr DOI: $10.1180 / 0009855043920126$ chemical conditions of the excavated zones. The introduction of air to subterranean galleries modifies the redox conditions and the hygrometry for a significant rock volume, generally up to $\sim 1 \mathrm{~m}$ from the gallery wall (Giraud et al., 1999). As a function of temperature and hygrometry variations, either dehydration (during winter) or water condensation (during summer) occurs. In the presence of adsorbed water, changes in redox conditions induce pyrite oxidation. Whatever the mechanism of pyrite oxidation (Garrels \& Thompson, 1960; Bailey \& Peters, 1976; Sévèque, 1986; Mustin, 1992), protons are produced (Panin et al., 1985) with a local decrease of the interstitial fluid pH (Blowes \& Jambor, 1990; Cathelineau et al., 1995). In the case of pyrite-rich mudstones, these processes at the pyrite-fluid interface may 
cause significant mineralogical changes. It has generally been observed that $\mathrm{pH}$ affects clayparticle stability, that it induces transformation or dissolution (Aoudjit et al., 1996; Galan et al., 1999) and that the dissolution rate of clay particles is greater at low pH values (Zysset \& Schindler, 1996; Bauer \& Berger, 1998; Huertas et al., 2001). These processes have been studied for pure minerals and for bulk soil properties, but to a much smaller extent for individual particles in carbonate-rich mudstones or shales, because the abundance of calcite is known to buffer fluid $\mathrm{pH}$, and is assumed to minimize the effect of the low-pH fluid produced by pyrite oxidation.

Over a long period, repeated dehydration processes could lead to a considerable decrease of the swelling and sorption capacities of smectite in I-S (Huang et al., 1995).

The French Institute for Radioprotection and Nuclear Safety (IRSN) has selected a site near Tournemire (Aveyron, France) for its research program on deep geological waste disposal in clay-rich rock formation. The site is used as a laboratory for generic scientific and geotechnical investigations in underground conditions. A railway tunnel was built $\sim 100$ y ago through a $250 \mathrm{~m}$ thick, indurated Toarcian mudstone and two galleries were constructed $5 \mathrm{y}$ ago. The mudstone formation occurs between two limestone formations in a sub-horizontal Jurassic sedimentary series (Barbreau \& Boisson, 1993; Fig. 1).

The disturbed zone around the tunnel is characterized by a 1-2 $\mathrm{m}$ thick sub-vertical fracture zone (Bonin, 1998) and by a significant dehydration of the rock (Giraud et al., 1999). Previous study of rock surfaces collected in the 'EDZ' (excavated disturbed zone) has already revealed significant changes in the mineralogy of block surfaces: mudstones are affected by oxidation in the presence of air and condensed water (Charpentier et al., 2001). Precipitates at the oxidized surface constitute a typical association of oxidation by-products (gypsum, celestine, jarosite and $\mathrm{Fe}$ hydroxides). Crystallization of jarosite, an $\mathrm{Fe}, \mathrm{K}$-sulphate, requires the local availability of $\mathrm{K}$ and a low-pH fluid. As the interstitial pore fluid is $\mathrm{K}$-poor, with a $\mathrm{Na} / \mathrm{K}$ ratio 20 (Charpentier, 2001), the most probable source of $\mathrm{K}$ is clay minerals. In fact, other K-bearers (such as feldspars) are rare and not affected by oxidation or alteration. The objectives of this study were therefore: (1) to evaluate the mineralogical and chemical modifications of the clay particles in the oxidized argillite; and (2) to estimate the role of acid waters in the change of the water-rock system and its effect on the stability of clay minerals.

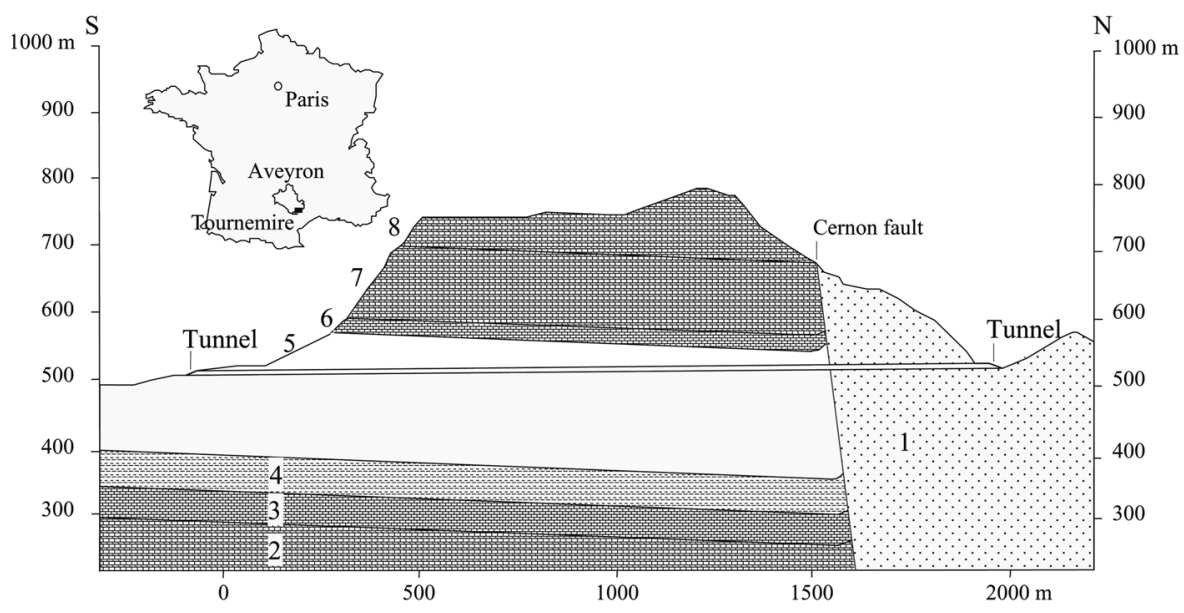

\footnotetext{
8 Bathonian: limestone and dolomite

7 Bajocian: limestone and dolomite

6 Aalenian: limestone

5 Toarcian: shales and marls
}

4 Domerian: marls
3 Carixian: limestone
2 Sinemurian: limestone and dolomite
1 Hettangian: limestone and dolomite

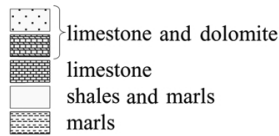

FIG. 1. Geological cross-section of the Tournemire tunnel with inset map showing the location of Tournemire (after Boisson, 1996). 


\section{GEOLOGICAL SETTING AND SAMPLING}

\section{Sampling}

Two sets of samples were taken, one from a preserved zone in the Toarcian formation and one from the tunnel wall exposed to air.

A sub-horizontal borehole, so-called IM, was drilled perpendicularly to the wall of the main $100 \mathrm{y}$ old tunnel (Fig. 2). The core was taken parallel to the stratigraphic layers, in order to minimize mineralogical changes due to primary sedimentation changes. Samples IM1420 and IM1435 were taken at different distances from the tunnel wall (14.20 and $14.35 \mathrm{~m}$, respectively), within zones unaffected by the oxidized front. Samples were wrapped and sealed in an evacuated Al-coated plastic bag under $\mathrm{N}_{2}$ atmosphere at the sampling site to ensure that the cores were as pristine as possible and that the contact time with air was minimal. The results obtained for the 'preserved samples' are presented together because no significant differences were noticed between them.

Sample EDF was taken within the tunnel wall. Samples GE50 and GE76 were collected in the eastern gallery at 50 and $76 \mathrm{~cm}$ from the tunnel wall. These samples, coming from the same stratigraphic plane as core samples, are considered to be the most affected by oxidation. The results obtained for this group of samples are presented together because no significant differences have been noticed between them. These samples were described in this article as 'oxidized samples'.

\section{Analytical procedures}

Bulk-rock mineralogy. Scanning electron microscopy (SEM) observations were carried out on rock fragments with an HITACHI ${ }^{\circledR}$ S2500 FEVEX microscope (University of Nancy, France). The SEM was fitted with an energy dispersive spectrometer (EDS) for chemical analysis using secondary X-rays and standard ZAF corrections that allow semi-quantitative microanalyses and characterization of phases.

$\mathrm{X}$-ray diffraction patterns were obtained between $3^{\circ} 2 \theta$ and $40^{\circ} 2 \theta$ using a Siemens ${ }^{\circledR}$ D5000 diffractometer $(35 \mathrm{kV}, 45 \mathrm{~mA})$ equipped with a Co tube (Laboratoire Environnement et Minéralurgie, France). The step size was $0.035^{\circ} 2 \theta$ and the counting time was $3 \mathrm{~s}$ per step.

Mineralogy and crystal chemistry of clay particles. After removal of carbonates by treatment with dilute $\mathrm{HCl}$ acid, the clay fractions $(<2 \mu \mathrm{m}$ grain size) were separated by suspension settled in distilled water. As illite, smectite and mixed-layer particles are the smaller particles, this fraction is enriched in those minerals if they are present.

Oriented aggregates of clay fractions on glass slides were analysed by X-ray diffraction (XRD). $\mathrm{X}$-ray diffraction patterns of air-dried and glycolated clay fractions were carried out on a Siemens ${ }^{\circledR}$

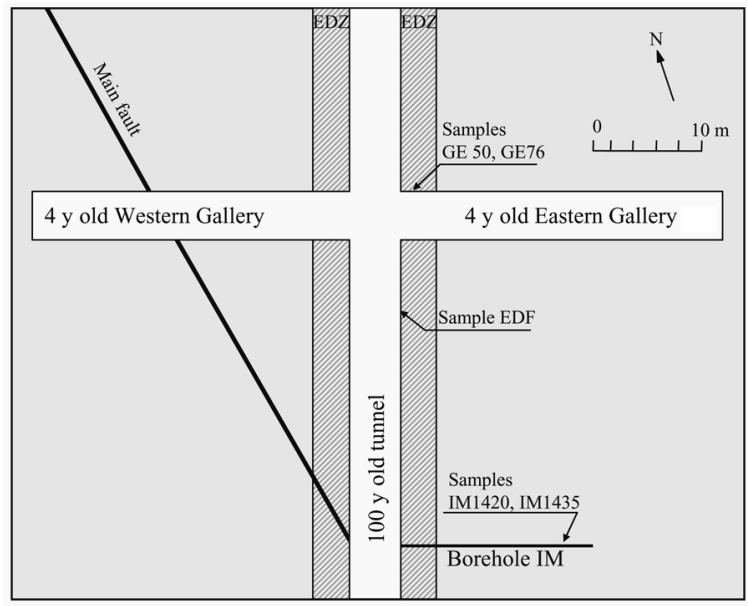

FIG. 2. Sample locations in the Tournemire site (EDZ: excavated disturbed zone of the tunnel) with: (1) EDF: $100 \mathrm{y}$ old tunnel; (2) GE50: 4 y old eastern gallery, $0.50 \mathrm{~m}$ from the tunnel wall; (3) GE76: 4 y old eastern gallery, $0.76 \mathrm{~m}$ from the tunnel wall; (4) IM1420: subhorizontal borehole, $14.20 \mathrm{~m}$ from the tunnel wall;

(5) IM1435: subhorizontal borehole, $14.35 \mathrm{~m}$ from the tunnel wall. 
D5000 diffractometer $(35 \mathrm{kV}, 45 \mathrm{~mA})$ equipped with a Co tube (Laboratoire Environnement et Minéralurgie, France). The step size was $0.035^{\circ} 2 \theta$ and the counting time was $3 \mathrm{~s}$ per step between $3^{\circ} 2 \theta$ and $40^{\circ} 2 \theta$. The spectra were treated using a 5-point smoothing routine and the background was subtracted from the total spectrum. A decomposition routine was then used to determine the position of the reflections, using Gaussian and LorentzGaussian options (Opus software, R. Bruker).

The clay-particle compositions of the fine fractions $(<2 \mu \mathrm{m})$ were determined by analytical transmission electron microscopy (ATEM) on well isolated particles oriented on carbon $\mathrm{Ni}$-grids to avoid analyses of mixtures. The microscope was a CM20-STEM working at $200 \mathrm{kV}$, using energy dispersive X-ray spectroscopy (EDXS) (University of Nancy, France). To avoid electron radiation damage, including element migration and mass loss, the acquisition time was reduced to $40 \mathrm{~s}$. The chemical formulae of particles were calculated assuming $\mathrm{Fe}$ as $\mathrm{Fe}$ (III) because the valence state of $\mathrm{Fe}$ is mostly $\mathrm{Fe}$ (III) in the studied minerals, as shown later. Structural formulae were calculated according to the method of Harvey (1943), i.e. on the basis of 11 oxygens for particles of 2:1-type (illite or smectite), on the basis of 14 oxygens for 2:1:1-type (chlorite), and on the basis of 7 oxygens for 1:1-type (kaolinite).

The valence state of $\mathrm{Fe}$ in mixed-layer illitesmectite (I-S) particles (determined by ATEM analyses) was determined using electron energyloss spectroscopy (EELS) in a TEM following the procedure of Guillaume et al. (2001). The fine fraction of samples was prepared for EELS by crushing under methanol, ultrasonic dispersion, followed by dropping of the suspension to dry on a Ni TEM grid. $\mathrm{MnBr}_{2}$ diluted in methanol is also disposed as a drop onto the grid to provide $\mathrm{Mn}^{2+}$ as an internal standard for the calibration of the spectra. The valence state of $\mathrm{Fe}$ was measured using the chemical shift of the $\mathrm{Fe}_{3}$ edge after calibration of the spectra with the $\mathrm{Mn}^{2+} \mathrm{L}_{3}$ edge.

\section{RESULTS}

\section{Bulk mineralogy}

Minerals were identified by coupling SEM observations, SEM-EDS analyses and XRD on bulk rock. Toarcian mudstone consists of detrital clay-rich laminae (biotite, chlorite, kaolinite, illite, interstratified I-S) cemented by carbonates. The coarse fraction also contains quartz ( 20 wt.\%), K-feldspars, bioclasts and pyrite. Carbonates (calcite with minor dolomite and siderite) constitute $\sim 15$ wt. $\%$ of the bulk-rock composition. Clay minerals represent $\sim 60 \mathrm{wt} . \%$. Pyrite is present in significant amounts $(\sim 3 \mathrm{wt} . \%)$ and occurs as framboids in bioclasts and carbonate layers, and as framboids and cubic crystals dispersed in the clay matrix (Fig. 3).

\section{Clay mineralogy $(<2 \mu \mathrm{m})$}

All XRD patterns of representative $<2 \mu \mathrm{m}$ fractions of oxidized and preserved samples (Fig. 4) present a reflection at $d_{h k l}=14.3 \AA$, which does not show any change after glycolation. This reflection is assigned to chlorite. The reflections at $d_{h k l}=10.0 \AA$ and $5.0 \AA$ which remain after ethylene glycol saturation are attributed to non-expendable dioctahedral layers (illite or mica). The asymmetrical reflection plotted at $d_{h k l}=$ $7.2 \AA$ can be attributed to the superposition of kaolinite and chlorite reflections. The relative proportion of phases in the clay fraction of preserved sample is about $40-50 \%$ illite, $15-25 \%$ mixed-layer I-S, 25-40\% kaolinite + chlorite (method of Holtzapffel, 1985).

Deconvolutions of XRD patterns of the glycolated samples were carried out in the $5-12^{\circ} 2 \theta$

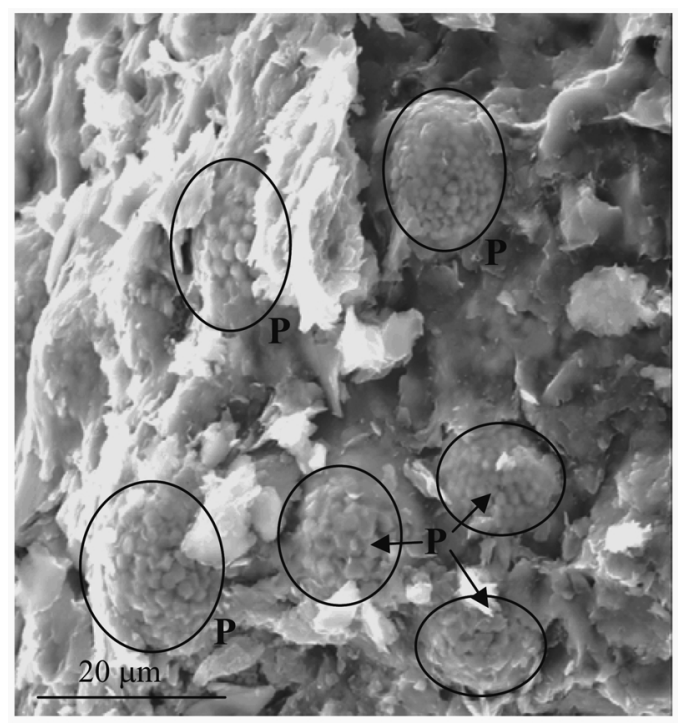

FIG. 3. SEM image of a framboidal pyrite aggregate

(P) in the I-S-rich matrix of a preserved sample. 

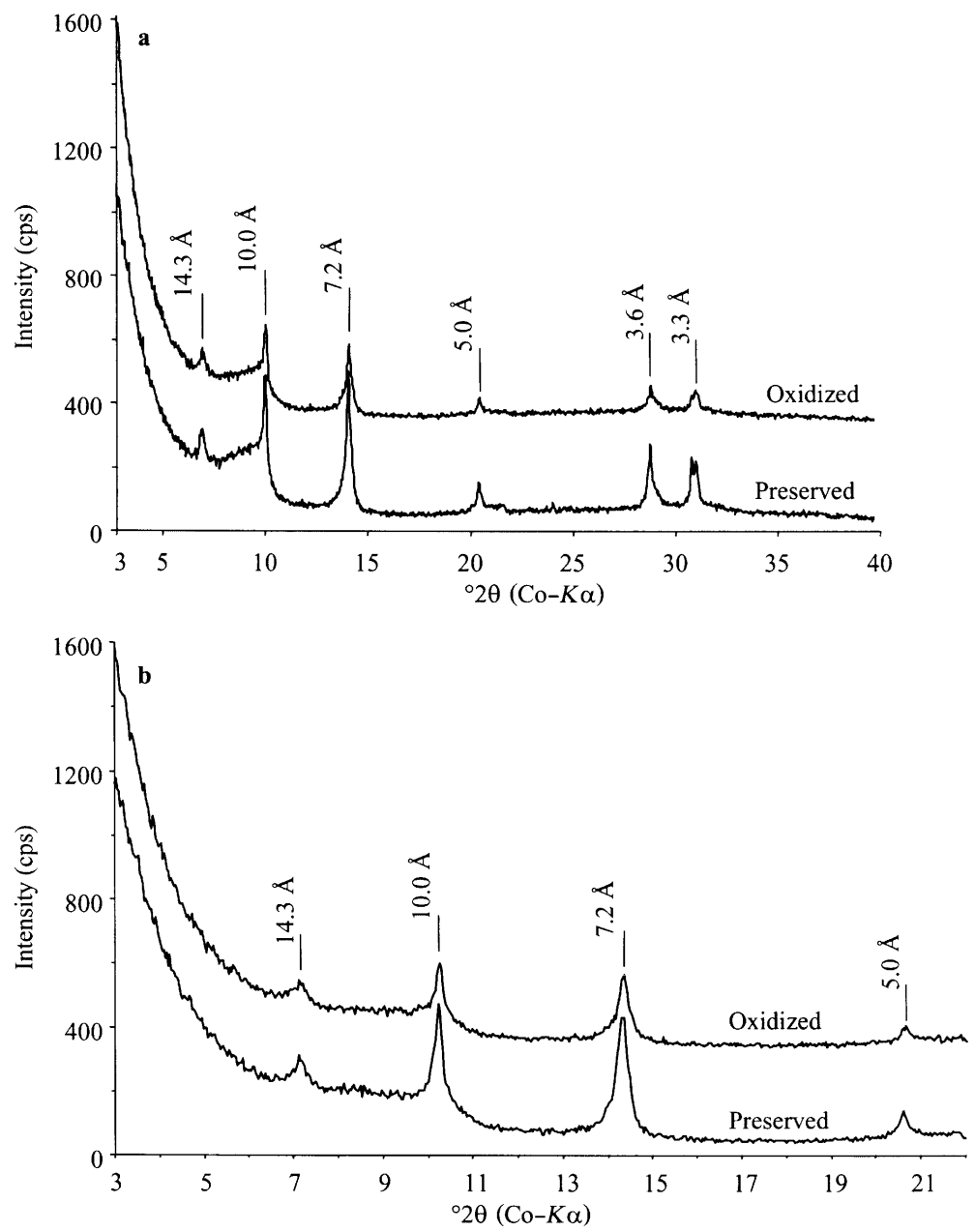

FIG. 4. Comparison of the XRD spectra obtained on the $<2 \mu \mathrm{m}$ fraction of a sample taken from the borehole (preserved) and a sample collected in the EDZ (oxidized): (a) air-dried sample; (b) glycolated sample.

domain (Fig. 5). The broad diffracted domain of preserved samples (Fig. 5a) is plotted between $d_{h k l}$ $=12.8$ and $10.2 \AA$. From the deconvolution results, it is assigned to a single mixed-layer phase with a reflection at $d_{h k l}=11.6 \AA$ and indicates a high proportion of illite layers $(>75 \%$, after Reynolds, 1980) in I-S particles.

The clay fraction of the oxidized samples is also characterized by a broad diffracted domain between $d_{h k l}=12.8$ and $10.2 \AA$ (Fig. 5b). But in that case, the best fit is obtained by two elementary peaks. The reflection at $d_{h k l}=10.2 \AA$ can be attributed to a mixed-layer I-S close to pure illite. The second reflection, assigned to the main mixed-layer I-S phase, shifts slightly towards lower $2 \theta$ values: it is located at $d_{h k l}=11.8 \AA$. In the case of the preserved samples, when the reflection at $d_{h k l}=$ $10.2 \AA$ is added in the deconvolution program, the results show that its intensity is very weak: it does not appear on the deconvoluated X-ray pattern.

Slight differences between the mineralogical composition of preserved and oxidized samples can be observed. In the oxidized sample, the mixedlayer I-S minerals are slightly richer in smectite layers, and another mineralogical phase close to pure illite (I-S with a very high proportion of illite layers) occurs in a minor but significantly larger amount than in the preserved sample. 

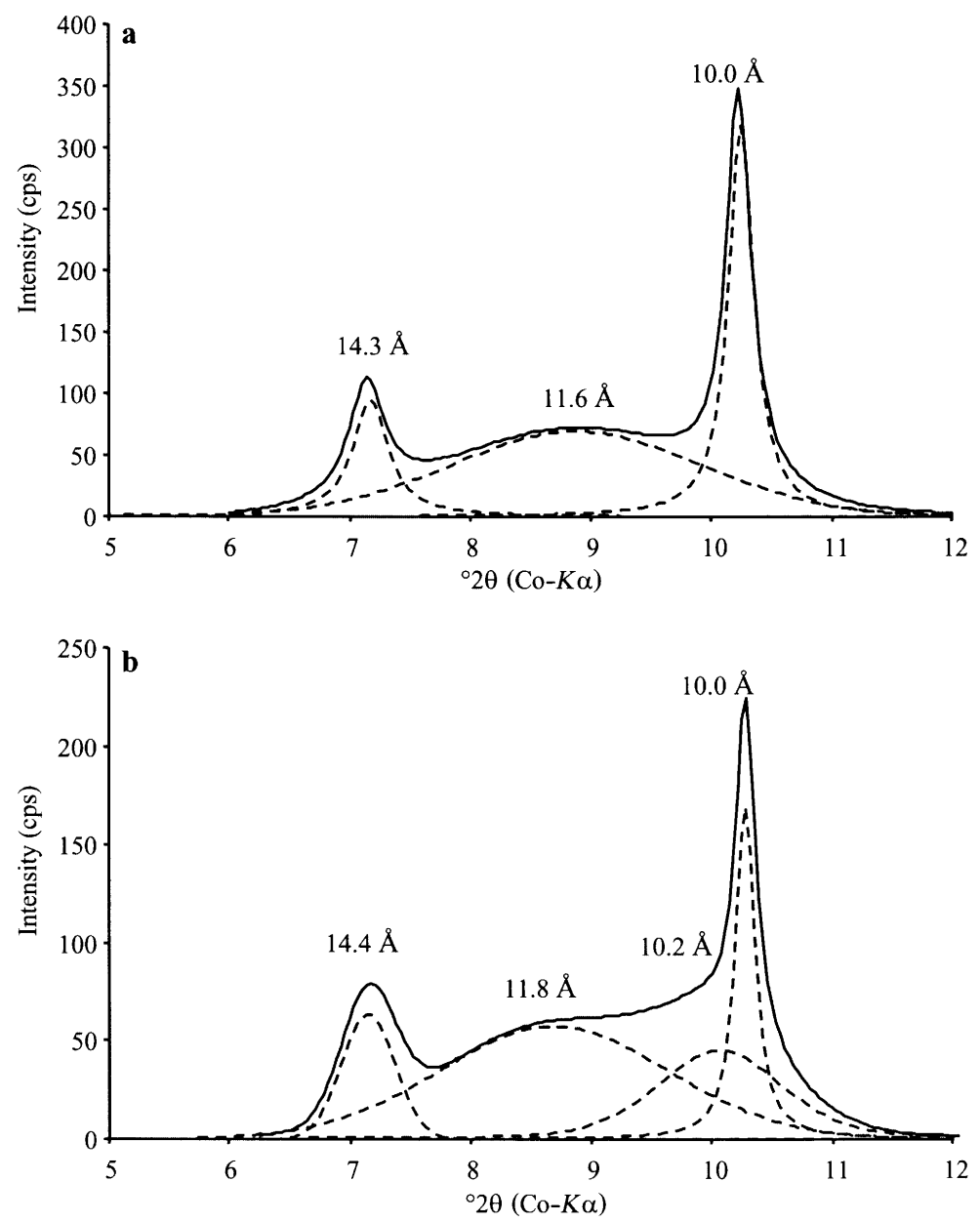

FIG. 5. XRD spectra of glycolated samples and decomposition using smoothed background correction: (a) preserved sample, (b) oxidized sample.

Chemical composition of clay minerals $(<2 \mu \mathrm{m})$

The discrimination of $2: 1,2: 1: 1$ and $1: 1$ phases was carried out on the basis of ATEM analyses of clay particles from the $<2 \mu \mathrm{m}$ fraction, plotted in a ternary MR3-2R3-3R2 diagram (Fig. 6; Velde, 1985).

The ATEM analyses of 2:1 particles (Tables 1 and 2) are plotted in a ternary celadonitemuscovite-pyrophyllite diagram (Fig. 7; Hower \& Mowatt, 1966). The data are spread between the illite and smectite domains, within the field of mixed-layer I-S. The scattering of the analyses suggests a large range in the relative contents of illite and smectite layers in I-S or mechanical mixing of mixed-layers at very small scale. The chemical composition of clay minerals (Table 3) from the preserved samples is close to the composition of the illite end-member, whereas those obtained for oxidized samples plot near the smectite domain. If it is assumed that illite layers and smectite layers have constant compositions, then the proportion of illite layers in the interstratified clays seems to be greater in the preserved samples than in the oxidized samples.

The main cation occupancies for the mixed-layer I-S particles are presented in Fig. 8. Site occupancy is calculated with 4 atoms of $\mathrm{Si}$ and $\mathrm{Al}$ per tetrahedral site, the remaining $\mathrm{Al}, \mathrm{Fe}$ and $\mathrm{Mg}$ being located in octahedral sites, with $\mathrm{Fe}$ considered as trivalent. 


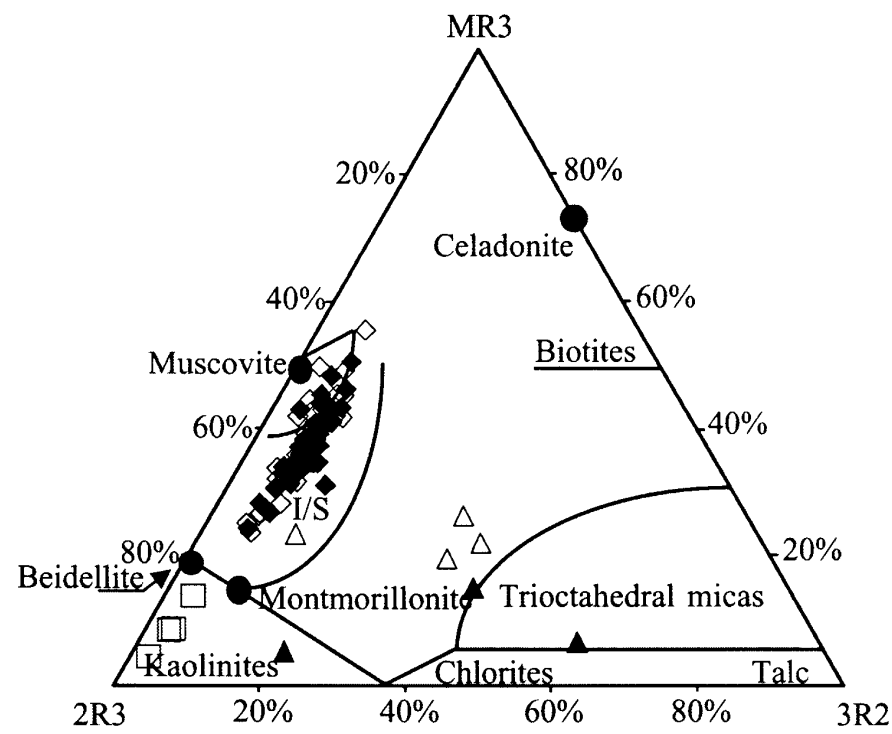

FIG. 6. ATEM analyses plotted on an MR3-2R3-3R2 diagram (Velde, 1985) with $\mathrm{MR} 3=\mathrm{Na}^{+}+\mathrm{K}^{+}+2 \mathrm{Ca}^{2+}$, $2 \mathrm{R} 3=\left(\mathrm{Al}^{3+}+\mathrm{Fe}^{3+}-\mathrm{MR} 3\right) / 2$ and $3 \mathrm{R} 2=\left(\mathrm{Mg}^{2+}+\mathrm{Mn}^{2+}+\mathrm{Fe}^{2+}\right) / 3$. The determination of $2: 1,2: 1: 1$ and $1: 1$ particles is based on chemistry. $\diamond-2: 1$ particles of preserved samples; $\triangle-2: 1: 1$ particles of preserved samples; $\square-1: 1$ particles of preserved samples; $--2: 1$ particles of oxidized samples; $\boldsymbol{\Delta}-2: 1: 1$ particles of oxidized samples.

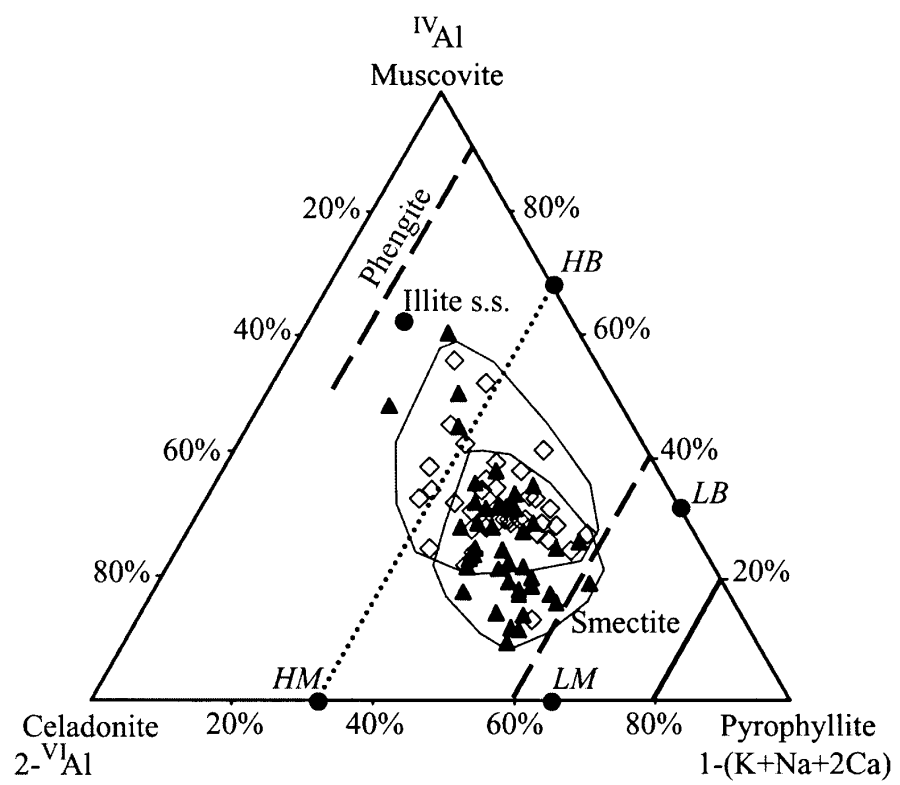

FIG. 7. ATEM analyses of 2:1 particles plotted in the Celadonite-Muscovite-Pyrophyllite diagram (Hower \& Mowatt, 1966). Compositions defined by Meunier \& Velde (1989): HB = high-charge beidellite, LB = lowcharge beidellite, $\mathrm{HM}=$ high-charge montmorillonite, $\mathrm{LM}=$ low-charge montmorillonite. $\diamond-$ preserved; $\boldsymbol{\Delta}$ - oxidized; $\mathbf{O}$ - end-member clays. 
TABLE 1. Chemical composition of mixed-layer I-S particles of preserved samples obtained by ATEM analyses (calculated on the basis of a half formula: values correspond to atom numbers calculated per 11 oxygen atoms. Calculations are made for 4 atoms of $\mathrm{Si}$ and $\mathrm{Al}$ per tetrahedral site,

$\mathrm{Al}$ remaining, $\mathrm{Fe}$ and $\mathrm{Mg}$ are located in the octahedral site, $\mathrm{Fe}$ is in the oxidized state).

\begin{tabular}{|c|c|c|c|c|c|c|c|c|c|c|}
\hline & $\mathrm{N}^{\mathrm{o}}$ & $\mathrm{Si}$ & ${ }^{\mathrm{IV}} \mathrm{Al}$ & $\mathrm{Al}_{\text {total }}$ & ${ }^{\mathrm{VI}} \mathrm{Al}$ & $\mathrm{Fe}^{3+}$ & $\mathrm{Mg}$ & $\mathrm{Ca}$ & $\mathrm{Na}$ & $\mathrm{K}$ \\
\hline \multirow[t]{31}{*}{ (a) } & 1 & 3.38 & 0.62 & 2.02 & 1.40 & 0.32 & 0.35 & 0.04 & 0.11 & 0.44 \\
\hline & 2 & 3.39 & 0.61 & 2.05 & 1.44 & 0.23 & 0.38 & 0.09 & 0.14 & 0.44 \\
\hline & 3 & 3.52 & 0.48 & 2.08 & 1.61 & 0.17 & 0.28 & 0.07 & 0.08 & 0.37 \\
\hline & 4 & 3.50 & 0.50 & 1.99 & 1.49 & 0.21 & 0.38 & 0.05 & 0.10 & 0.46 \\
\hline & 5 & 3.39 & 0.61 & 2.13 & 1.52 & 0.24 & 0.37 & 0.04 & 0.08 & 0.34 \\
\hline & 6 & 3.68 & 0.32 & 1.84 & 1.51 & 0.14 & 0.25 & 0.03 & 0.07 & 0.70 \\
\hline & 7 & 3.37 & 0.63 & 2.30 & 1.67 & 0.14 & 0.28 & 0.04 & 0.07 & 0.46 \\
\hline & 8 & 3.63 & 0.37 & 1.79 & 1.42 & 0.25 & 0.35 & 0.03 & 0.08 & 0.47 \\
\hline & 9 & 3.43 & 0.57 & 2.10 & 1.52 & 0.21 & 0.30 & 0.06 & 0.06 & 0.35 \\
\hline & 10 & 3.49 & 0.51 & 2.07 & 1.56 & 0.17 & 0.31 & 0.07 & 0.06 & 0.48 \\
\hline & 11 & 3.38 & 0.62 & 2.40 & 1.78 & 0.11 & 0.20 & 0.02 & 0.06 & 0.45 \\
\hline & 12 & 3.44 & 0.56 & 2.10 & 1.55 & 0.19 & 0.38 & 0.06 & 0.08 & 0.35 \\
\hline & 13 & 3.47 & 0.53 & 2.21 & 1.68 & 0.16 & 0.25 & 0.03 & 0.05 & 0.37 \\
\hline & 14 & 3.40 & 0.60 & 2.01 & 1.42 & 0.34 & 0.35 & 0.02 & 0.05 & 0.46 \\
\hline & 15 & 3.53 & 0.47 & 2.10 & 1.62 & 0.12 & 0.28 & 0.02 & 0.08 & 0.51 \\
\hline & 16 & 3.41 & 0.59 & 2.13 & 1.54 & 0.24 & 0.29 & 0.03 & 0.10 & 0.51 \\
\hline & 17 & 3.49 & 0.51 & 2.12 & 1.61 & 0.16 & 0.30 & 0.07 & 0.04 & 0.39 \\
\hline & 18 & 3.41 & 0.59 & 2.18 & 1.59 & 0.18 & 0.29 & 0.04 & 0.05 & 0.46 \\
\hline & 19 & 3.38 & 0.62 & 2.23 & 1.62 & 0.19 & 0.28 & 0.07 & 0.06 & 0.38 \\
\hline & 20 & 3.60 & 0.40 & 1.95 & 1.55 & 0.22 & 0.27 & 0.01 & 0.04 & 0.49 \\
\hline & 21 & 3.54 & 0.46 & 2.20 & 1.73 & 0.15 & 0.19 & 0.01 & 0.02 & 0.33 \\
\hline & 22 & 3.50 & 0.50 & 2.15 & 1.65 & 0.13 & 0.25 & 0.02 & 0.02 & 0.55 \\
\hline & 23 & 3.51 & 0.49 & 2.22 & 1.73 & 0.11 & 0.14 & 0.08 & 0.15 & 0.33 \\
\hline & 24 & 3.50 & 0.50 & 2.06 & 1.56 & 0.25 & 0.26 & 0.04 & 0.04 & 0.36 \\
\hline & 25 & 3.49 & 0.51 & 2.14 & 1.63 & 0.23 & 0.23 & 0.05 & 0.04 & 0.28 \\
\hline & 26 & 3.77 & 0.23 & 1.71 & 1.48 & 0.26 & 0.29 & 0.06 & 0.02 & 0.21 \\
\hline & 27 & 3.54 & 0.46 & 1.84 & 1.38 & 0.32 & 0.32 & 0.06 & 0.04 & 0.39 \\
\hline & 28 & 3.58 & 0.42 & 2.08 & 1.66 & 0.15 & 0.22 & 0.03 & 0.07 & 0.33 \\
\hline & 29 & 3.62 & 0.38 & 2.09 & 1.71 & 0.14 & 0.23 & 0.04 & 0.01 & 0.24 \\
\hline & 30 & 3.53 & 0.47 & 2.15 & 1.69 & 0.17 & 0.23 & 0.03 & 0.05 & 0.28 \\
\hline & 31 & 3.48 & 0.52 & 2.22 & 1.70 & 0.09 & 0.21 & 0.01 & 0.06 & 0.59 \\
\hline
\end{tabular}

The tetrahedral site is occupied for most of the mixed-layer I-S minerals from the preserved samples by $3.4-3.5 \mathrm{Si}$ atoms (per half unit cell) and for I-S from the oxidized samples by 3.6-3.7 Si. The I-S particles of oxidized samples are all richer in $\mathrm{Si}$ than the mixed-layer particles of preserved samples.

Most analyses of both preserved and oxidized samples indicate contents of $\sim 0.15 \mathrm{Fe}$ and $0.25 \mathrm{Mg}$ per 11 oxygen atoms. The $\mathrm{Al}$ content in octahedral sites is more important in preserved samples than in oxidized samples ( 1.6-1.7 and 1.5-1.6).

In preserved samples, the interlayer occupancy of $\mathrm{I}-\mathrm{S}$ particles is dominated by $\mathrm{K}$, which ranges from 0.2 to 0.8 atoms with a mode at $0.3-0.4$. The $\mathrm{Na}$ and $\mathrm{Ca}$ contents are variable $(\mathrm{Na}$ from 0 to 0.16 , and $\mathrm{Ca}$ from 0 to 0.09). In oxidized samples, the $\mathrm{K}$ and $\mathrm{Ca}$ contents are similar to those from preserved samples, but the $\mathrm{Na}$ content is slightly higher $(0-0.2)$.

In summary, mixed-layer I-S from the oxidized zone is enriched in $\mathrm{Si}$, but is poorer in $\mathrm{Al}$. The $\mathrm{Mg}$ and $\mathrm{Fe}$ contents remain approximately constant.

\section{Oxidation status of $\mathrm{Fe}$}

EELS spectra have been obtained for I-S mixed layers (identified by ATEM) in both sets of samples. The $\mathrm{Fe}$ (III)/total $\mathrm{Fe}$ ratio for mixed-layer I-S particles (Fig. 9) varies from 0.3 to 1 with a mode of $\sim 0.6$ or 0.7 in preserved samples and from 0.4 to 1 with a mode of 0.7 in oxidized samples. In 
TABLE 2. Chemical composition of mixed-layer I-S particles of oxidized samples obtained by ATEM analyses (calculated on the basis of a half formula).

\begin{tabular}{|c|c|c|c|c|c|c|c|c|c|}
\hline $\mathrm{N}^{\mathrm{o}}$ & $\mathrm{Si}$ & ${ }^{\mathrm{IV}} \mathrm{Al}$ & $\mathrm{Al}$ & ${ }^{\mathrm{VI}} \mathrm{Al}$ & $\mathrm{Fe}^{3+}$ & $\mathrm{Mg}$ & $\mathrm{Ca}$ & $\mathrm{Na}$ & K \\
\hline 1 & 3.73 & 0.27 & 1.81 & 1.54 & 0.19 & 0.25 & 0.05 & 0.06 & 0.35 \\
\hline 2 & 3.62 & 0.38 & 2.13 & 1.75 & 0.10 & 0.20 & 0.04 & 0.03 & 0.29 \\
\hline 3 & 3.47 & 0.53 & 2.18 & 1.65 & 0.17 & 0.23 & 0.02 & 0.06 & 0.43 \\
\hline 4 & 3.62 & 0.38 & 2.06 & 1.68 & 0.13 & 0.23 & 0.03 & 0.06 & 0.31 \\
\hline 5 & 3.72 & 0.28 & 2.00 & 1.72 & 0.13 & 0.19 & 0.03 & 0.05 & 0.21 \\
\hline 6 & 3.61 & 0.39 & 1.93 & 1.54 & 0.22 & 0.27 & 0.03 & 0.06 & 0.40 \\
\hline 7 & 3.85 & 0.15 & 1.73 & 1.57 & 0.17 & 0.22 & 0.03 & 0.05 & 0.38 \\
\hline 8 & 3.62 & 0.38 & 1.85 & 1.47 & 0.19 & 0.36 & 0.03 & 0.11 & 0.49 \\
\hline 9 & 3.47 & 0.53 & 2.24 & 1.71 & 0.13 & 0.25 & 0.02 & 0.06 & 0.42 \\
\hline 10 & 3.52 & 0.48 & 2.05 & 1.58 & 0.15 & 0.32 & 0.02 & 0.07 & 0.50 \\
\hline 11 & 3.85 & 0.15 & 1.73 & 1.57 & 0.17 & 0.23 & 0.01 & 0.04 & 0.38 \\
\hline 12 & 3.52 & 0.48 & 2.12 & 1.64 & 0.13 & 0.28 & 0.01 & 0.08 & 0.43 \\
\hline 13 & 3.63 & 0.37 & 1.89 & 1.52 & 0.21 & 0.27 & 0.03 & 0.05 & 0.48 \\
\hline 14 & 3.34 & 0.66 & 2.06 & 1.41 & 0.32 & 0.43 & 0.05 & 0.08 & 0.40 \\
\hline 15 & 3.42 & 0.58 & 2.23 & 1.64 & 0.12 & 0.22 & 0.02 & 0.13 & 0.58 \\
\hline 16 & 3.68 & 0.32 & 1.64 & 1.32 & 0.34 & 0.38 & 0.03 & 0.08 & 0.35 \\
\hline 17 & 3.65 & 0.35 & 1.90 & 1.56 & 0.20 & 0.30 & 0.03 & 0.07 & 0.32 \\
\hline 18 & 3.78 & 0.22 & 1.69 & 1.46 & 0.23 & 0.28 & 0.05 & 0.06 & 0.38 \\
\hline 19 & 3.68 & 0.32 & 1.84 & 1.53 & 0.16 & 0.33 & 0.03 & 0.16 & 0.31 \\
\hline 20 & 3.70 & 0.30 & 1.81 & 1.51 & 0.16 & 0.26 & 0.05 & 0.19 & 0.45 \\
\hline 21 & 3.76 & 0.24 & 1.86 & 1.62 & 0.13 & 0.27 & 0.04 & 0.07 & 0.28 \\
\hline 22 & 3.59 & 0.41 & 2.05 & 1.64 & 0.12 & 0.25 & 0.03 & 0.08 & 0.43 \\
\hline 23 & 3.68 & 0.32 & 1.89 & 1.57 & 0.16 & 0.25 & 0.05 & 0.08 & 0.36 \\
\hline 24 & 3.87 & 0.13 & 1.64 & 1.51 & 0.17 & 0.27 & 0.04 & 0.04 & 0.37 \\
\hline 25 & 3.51 & 0.49 & 2.00 & 1.51 & 0.23 & 0.34 & 0.03 & 0.08 & 0.42 \\
\hline 26 & 3.63 & 0.37 & 1.82 & 1.45 & 0.22 & 0.35 & 0.03 & 0.07 & 0.46 \\
\hline 27 & 3.58 & 0.42 & 1.73 & 1.32 & 0.31 & 0.51 & 0.04 & 0.06 & 0.31 \\
\hline 28 & 3.64 & 0.36 & 1.84 & 1.48 & 0.23 & 0.31 & 0.06 & 0.06 & 0.39 \\
\hline 29 & 3.47 & 0.53 & 2.12 & 1.59 & 0.20 & 0.29 & 0.03 & 0.07 & 0.43 \\
\hline 30 & 3.74 & 0.26 & 1.88 & 1.62 & 0.14 & 0.25 & 0.05 & 0.05 & 0.30 \\
\hline 31 & 3.53 & 0.47 & 2.11 & 1.64 & 0.19 & 0.29 & 0.03 & 0.04 & 0.31 \\
\hline 32 & 3.79 & 0.21 & 1.75 & 1.53 & 0.18 & 0.28 & 0.04 & 0.07 & 0.33 \\
\hline 33 & 3.71 & 0.29 & 1.83 & 1.54 & 0.19 & 0.30 & 0.02 & 0.06 & 0.36 \\
\hline 34 & 3.55 & 0.45 & 1.93 & 1.48 & 0.19 & 0.34 & 0.03 & 0.11 & 0.56 \\
\hline 35 & 3.50 & 0.50 & 1.97 & 1.48 & 0.23 & 0.33 & 0.04 & 0.10 & 0.48 \\
\hline 36 & 3.66 & 0.34 & 1.90 & 1.56 & 0.18 & 0.25 & 0.04 & 0.08 & 0.43 \\
\hline 37 & 3.52 & 0.48 & 2.09 & 1.61 & 0.13 & 0.33 & 0.05 & 0.00 & 0.48 \\
\hline 38 & 3.44 & 0.56 & 2.13 & 1.57 & 0.17 & 0.35 & 0.00 & 0.12 & 0.54 \\
\hline
\end{tabular}

TABLE 3. Average composition of mixed-layer I-S particles obtained by ATEM analyses.

\begin{tabular}{llcccccccc}
\hline \multirow{2}{*}{$\mathrm{N}^{\mathrm{o}}$} & $\mathrm{Si}$ & ${ }^{\mathrm{IV}} \mathrm{Al}$ & ${ }^{\mathrm{VI}} \mathrm{Al}$ & $\mathrm{Fe}^{3+}$ & $\mathrm{Mg}$ & $\mathrm{Ca}$ & $\mathrm{Na}$ & $\mathrm{K}$ \\
\hline \multirow{2}{*}{ Preserved } & Mean value & 3.50 & 0.50 & 1.58 & 0.19 & 0.28 & 0.04 & 0.06 & 0.41 \\
\multirow{3}{*}{ Oxidized } & 0.09 & 0.09 & 0.10 & 0.06 & 0.06 & 0.02 & 0.03 & 0.10 \\
& Standard variation & 3.62 & 0.38 & 1.55 & 0.18 & 0.29 & 0.03 & 0.07 & 0.40 \\
& Mean value & 0.13 & 0.13 & 0.10 & 0.05 & 0.06 & 0.01 & 0.04 & 0.08 \\
& Standard variation & & & & & & & & \\
\hline
\end{tabular}



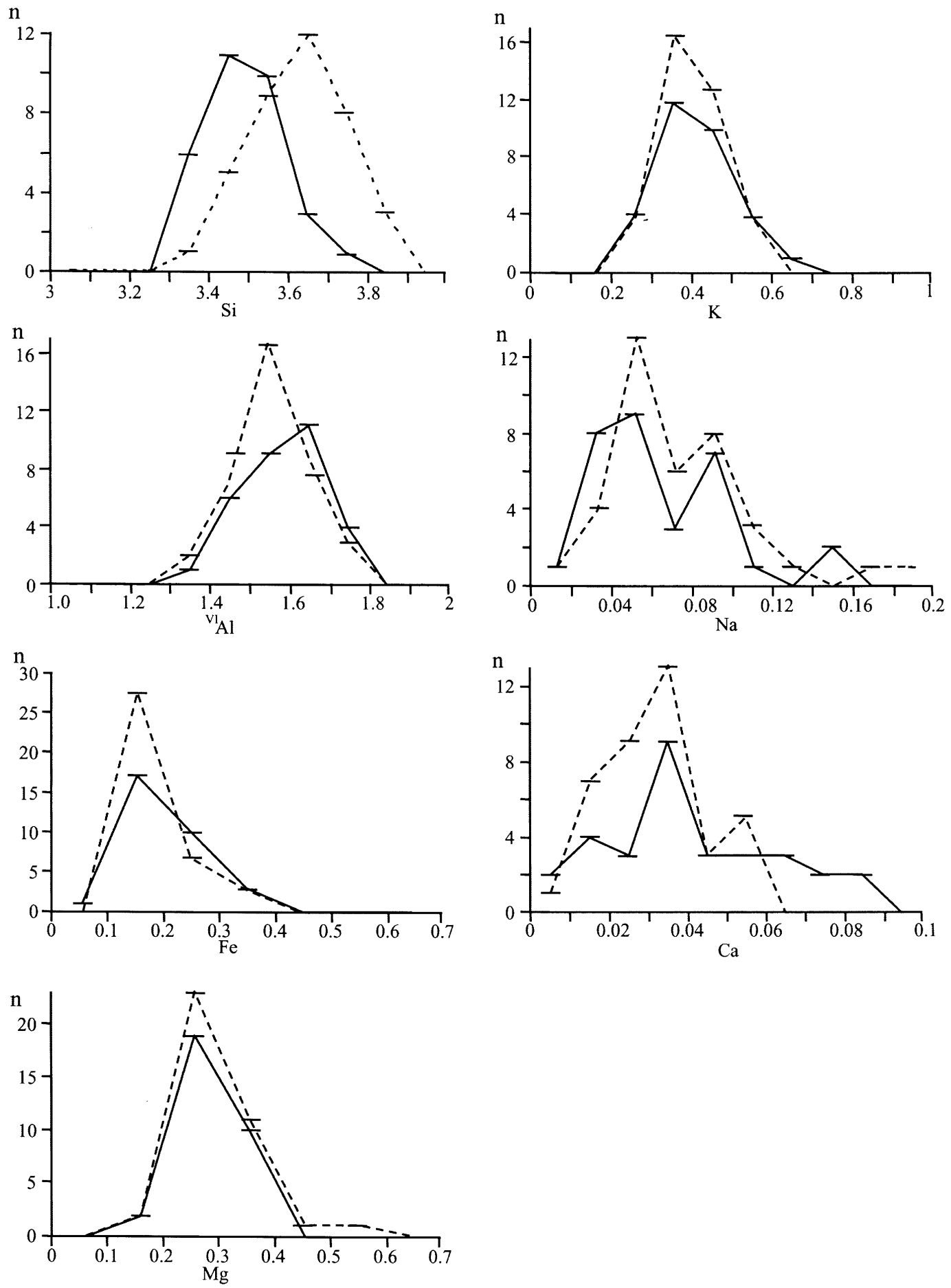

FIG. 8. Distribution of mixed-layer particle chemistry from ATEM data; atom numbers calculated per 11 oxygens. Solid lines: particles from preserved samples; dotted lines: particles from oxidized samples; $n$ : number of analyses. 


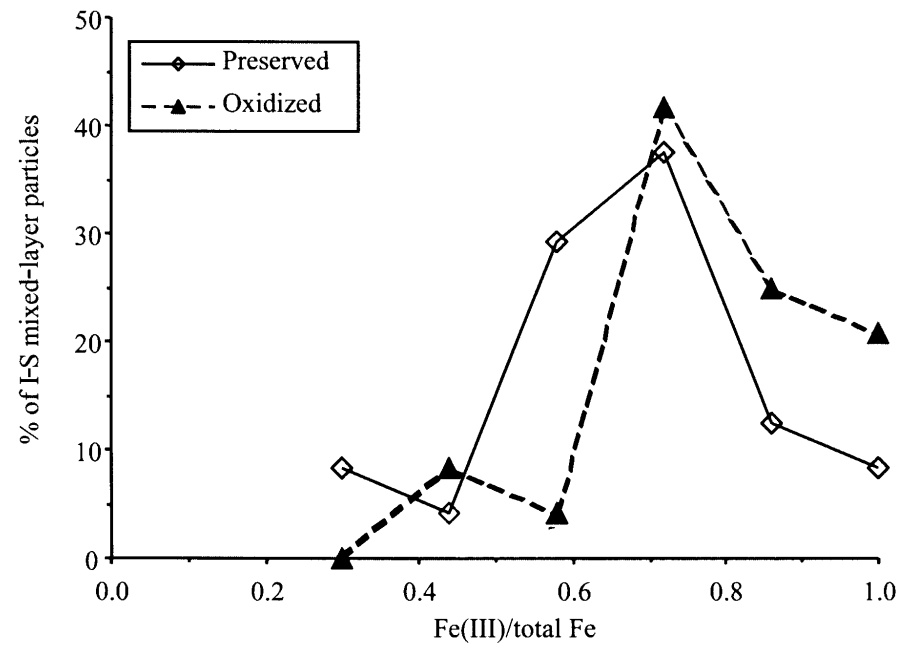

FIG. 9. Distribution of $\mathrm{Fe}(\mathrm{III}) / \mathrm{Fe}_{\text {total }}$ in I-S mixed-layer particles obtained by EELS analyses.

the case of oxidized samples, a significant number of particles has $\mathrm{Fe}(\mathrm{III}) /$ total $\mathrm{Fe}$ ratios of 0.85 to 1 and a few particles have a ratio of 0.4 to 0.6 .

The EELS analyses show that the relative amount of $\mathrm{Fe}$ (III) in mixed-layer I-S particles is greater in the oxidized sample $(>0.7)$. This change in the Fe valence in I-S minerals might be attributed to oxidation.

\section{Numerical modelling}

In the 'EDZ', cyclic hydrological changes occur with seasonal periods of dehydration and periods of water condensation. Condensation water is delivered to bulk rock during summer, a period of maximum humidity. During this period, oxidation of pyrite and localized acid release may occur. Clay particles around oxidized pyrite may be affected by acid sulphate-rich waters before their buffering by calcite dissolution.

Direct sampling of in situ groundwater was impossible because permeability and pore-fluid content were too low $\left(10^{-13} \mathrm{~m} / \mathrm{s}\right.$ and $3.5 \mathrm{wt} . \%$, respectively, in the formation: Bonin, 1998; De Windt et al., 1998). Changes in water chemistry at the interface between clay particles and oxidized pyrite have been investigated by numerical modelling which was carried out using the geochemical code EQ3/6 (Wolery \& Daveler, 1992). Assuming the solution to be a diluted water, the activity coefficient model of Debye-Hückel with the B-dot equation of Helgeson (1969) was used. The modelling conditions were as follows: constant temperature $\left(25^{\circ} \mathrm{C}\right)$, closed system and constant oxygen fugacity fixed as equal to the atmospheric oxygen fugacity $\left(\log f_{\mathrm{O}_{2}}=-0.68\right)$.

The first step of the water-rock interaction simulates the interaction between pure water representing the water issued from the condensation process $(\mathrm{pH}=5.8)$ and pyrite. The fluid composition after reaction is given in Table 4 . The second step considers the interaction of the latter fluid resulting from pyrite oxidation with the surrounding clay minerals. As the alteration of pyrite affects only illite and smectite, and not chlorite and kaolinite, the minerals considered are illite and Na-montmorillonite, the montmorillonite:illite molar ratio being 1:4.

The interaction between the fluid resulting from pyrite alteration and Na-montmorillonite, illite and pyrite produces an increase of $\mathrm{Si}, \mathrm{Al}, \mathrm{K}, \mathrm{Na}$ and $\mathrm{Mg}$ in simulated solution (Fig. 10, Table 4). Because of pyrite dissolution, the calculated $\mathrm{pH}$ value is low, between 3.8 and 3.9. The Fe content in solution remains constant, the solution being saturated with respect to hematite (Fig. 11). Minerals which are predicted to form are gibbsite, kaolinite, nontronite and quartz. The appearance of nontronite between the new phases indicates that the smectite is stable in this system and must be richer in Fe than the starting montmorillonite.

\section{DISCUSSION AND CONCLUSION}

Underground mechanical excavation, e.g. galleries for waste storage or railway tunnels implies 


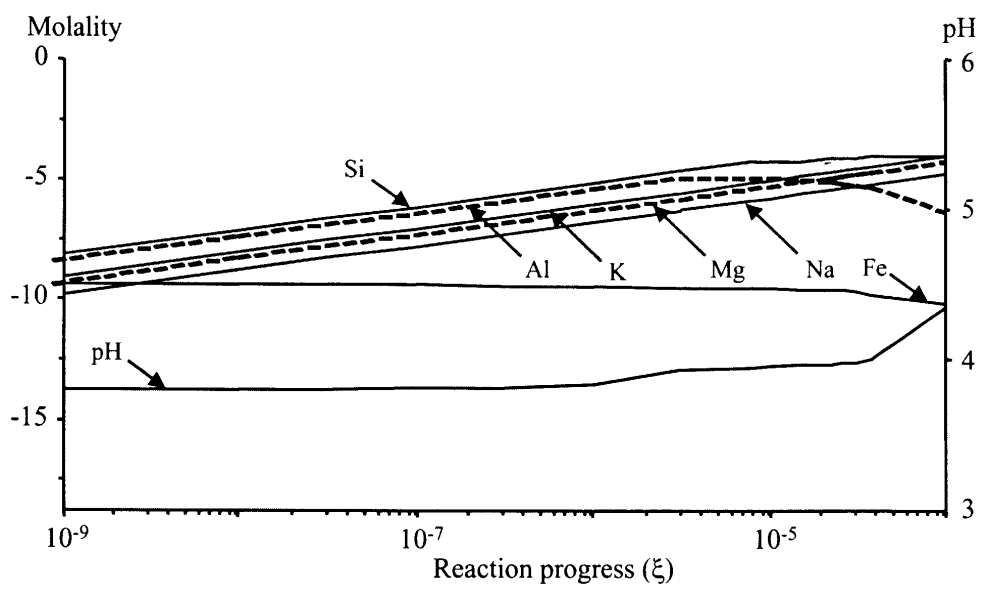

FIG. 10. Evolution of the fluid composition during modelling. The reaction progress consists of a progressive destruction of input minerals.

modification of the redox conditions and hygrometry variations. In the presence of adsorbed water, changes in redox conditions induce pyrite oxidation.

The impact of oxidation over $100 \mathrm{y}$ on the structural and chemical features of clay minerals in 'EDZ' zone is tenuous and localized at the rock surfaces in the case of the Tournemire formation. The AEM analyses show some chemical differences between the mixed-layer I-S clay particles of the two sets of samples (oxidized and preserved), especially an enrichment in $\mathrm{Na}$ and $\mathrm{Si}$ of the I-S minerals from the oxidized samples. If the initial compositions of illite and smectite in the mixedlayer I-S are assumed to be poorly variable in the formation, the changes in I-S composition can be attributed to a decrease in the illite content of the mixed-layer I-S in response to alteration.

Such changes might be explained by two mechanisms: (1) a transformation of illite layers into smectite layers; or (2) a destruction of illite layers.

The formation of smectitic clay particles through the transformation of a precursor mica or illite has already been observed in soils under the influence of climatic modifications or seasonal cycles (Velde \& Church, 1999; Gillot et al., 2000). This transformation, so-called aggradation by Millot (1964) involves an addition of silicon. The following overall reaction illite $+\mathrm{Si}^{4+}=$ smectite $+\mathrm{K}^{+}+\mathrm{Al}^{3+}$ was given by Pusch \& Karnland

TABLE 4. Chemical composition of the modelled fluid. Fluid 1 is issued from the interaction between pure water and pyrite; Fluid 2 results from the interaction of fluid 1 with $25 \% \mathrm{Na}$ montmorillonite and $75 \%$ illite at three steps: (2a) at kaolinite oversaturation, (2b) at nontronite oversaturation, (3) at equilibrium.

\begin{tabular}{|c|c|c|c|c|c|}
\hline & & 1 & $2 \mathrm{a}$ & $2 b$ & 3 \\
\hline $\mathrm{H}^{+}$ & $\mathrm{pH}$ & 3.8 & 3.9 & 4.0 & 4.3 \\
\hline $\mathrm{SiO}_{2}$ & $\left(\mathrm{~mol} / \mathrm{kg}_{\mathrm{H}_{2} \mathrm{O}}\right)$ & $1.0 \mathrm{e}^{-20}$ & $6.5 \mathrm{e}^{-5}$ & $7.1 \mathrm{e}^{-5}$ & $1.1 \mathrm{e}^{-4}$ \\
\hline $\mathrm{Al}^{3+}$ & $\left(\mathrm{mol} / \mathrm{kg}_{\mathrm{H}_{2} \mathrm{O}}\right)$ & $1.0 \mathrm{e}^{-20}$ & $1.3 \mathrm{e}^{-5}$ & $1.1 \mathrm{e}^{-5}$ & $5.1 \mathrm{e}^{-7}$ \\
\hline $\mathrm{Mg}^{2+}$ & $\left(\mathrm{mol} / \mathrm{kg}_{\mathrm{H}_{2} \mathrm{O}}\right)$ & $1.0 \mathrm{e}^{-20}$ & $1.7 \mathrm{e}^{-6}$ & $8.3 \mathrm{e}^{-6}$ & $5.4 \mathrm{e}^{-5}$ \\
\hline $\mathrm{Ca}^{2+}$ & $\left(\mathrm{mol} / \mathrm{kg}_{\mathrm{H}_{2} \mathrm{O}}\right)$ & $1.0 \mathrm{e}^{-20}$ & $2.5 \mathrm{e}^{-20}$ & $2.5 \mathrm{e}^{-20}$ & $2.5 \mathrm{e}^{-20}$ \\
\hline $\mathrm{Na}^{+}$ & $\left(\mathrm{mol} / \mathrm{kg}_{\mathrm{H}_{2} \mathrm{O}}\right)$ & $1.0 \mathrm{e}^{-20}$ & $5.2 \mathrm{e}^{-7}$ & $2.5 \mathrm{e}^{-6}$ & $1.7 \mathrm{e}^{-5}$ \\
\hline $\mathrm{K}^{+}$ & $\left(\mathrm{mol} / \mathrm{kg}_{\mathrm{H}_{2} \mathrm{O}}\right)$ & $1.0 \mathrm{e}^{-20}$ & $2.8 \mathrm{e}^{-6}$ & $1.4 \mathrm{e}^{-5}$ & $9.0 \mathrm{e}^{-5}$ \\
\hline $\mathrm{HCO}_{3}^{-}$ & $\left(\mathrm{mol} / \mathrm{kg}_{\mathrm{H}_{2} \mathrm{O}}\right)$ & $1.0 \mathrm{e}^{-20}$ & $1.6 \mathrm{e}^{-20}$ & $1.6 \mathrm{e}^{-20}$ & $1.6 \mathrm{e}^{-20}$ \\
\hline $\mathrm{Fe}^{2+}$ & $\left(\mathrm{mol} / \mathrm{kg}_{\mathrm{H}_{2} \mathrm{O}}\right)$ & $3.2 \mathrm{e}^{-10}$ & $2.9 \mathrm{e}^{-10}$ & $2.7 \mathrm{e}^{-10}$ & $6.9 \mathrm{e}^{-11}$ \\
\hline $\mathrm{SO}_{4}^{2-}$ & $\left(\mathrm{mol} / \mathrm{kg}_{\mathrm{H}_{2} \mathrm{O}}\right)$ & $6.3 \mathrm{e}^{-5}$ & $6.4 \mathrm{e}^{-5}$ & $7.1 \mathrm{e}^{-5}$ & $1.1 \mathrm{e}^{-4}$ \\
\hline
\end{tabular}




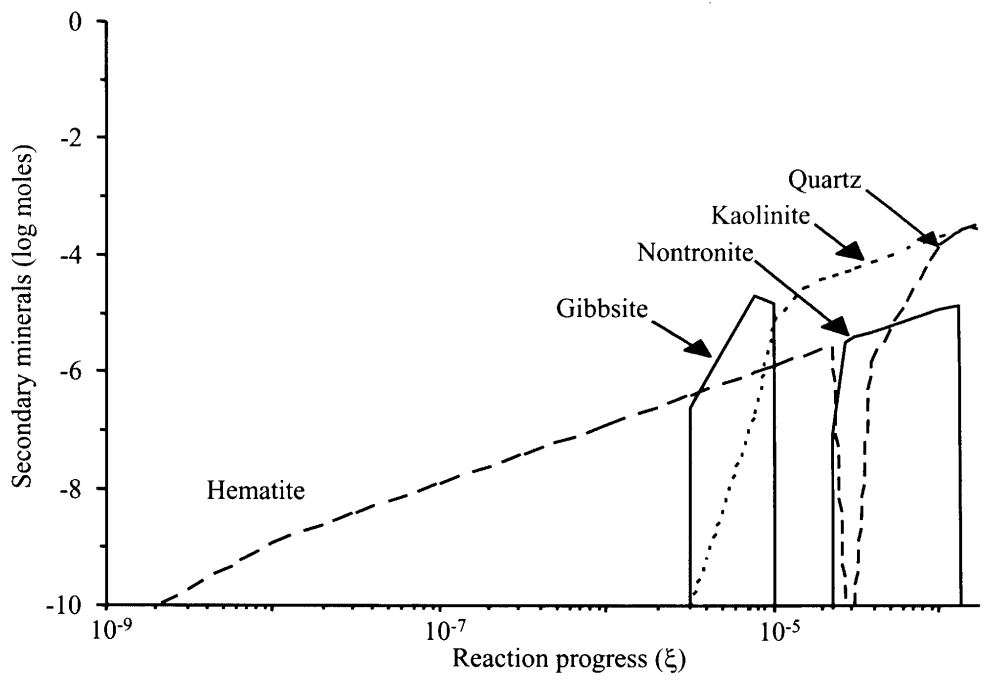

FIG. 11. Evolution of the secondary mineral assemblage predicted by modelling. The reaction progress consists of a progressive destruction of starting minerals.

(1996). Although generally the source of $\mathrm{Si}$ involved is feldspar or quartz, no evidence of dissolution of these minerals could be established in the oxidized samples (Charpentier et al., 2001).

Illite particles may be relatively unstable when oxidation-reduction cycles or cyclic hydrological changes occur (Teveldal et al., 1990) if the $a_{\mathrm{K}^{+}} / a_{\mathrm{H}^{+}}$is low. Partial dissolution of illite is possible in areas exposed to oxidation and to a $\mathrm{pH}$ decrease (Raz \& Peters, 1989; Wilson, 1999). Thus, according to the activity diagram showing the stability relations between muscovite, illite and smectite, the decrease of $\mathrm{pH}$ yields an increased stability of smectite relative to illite. It may explain the preferential dissolution of illite layers in mixedlayer I-S surrounding oxidized pyrite.

As shown by the numerical modelling, the composition of the fluid interacting with the mineral association "pyrite + illite + smectite" changes towards the stability domain of smectite, supporting the observation that the smectite is more stable than illite. During the preferential degradation of illite layers, no modification of the octahedral composition of bulk mixed-layer I-S is noticed, except an increase in the relative oxidation status of $\mathrm{Fe}$. This result indicates that illite and smectite layers should have a rather similar octahedral site composition. Transitory phases predicted by the numerical simulation (kaolinite, gibbsite) were not observed in natural samples possibly because they are present in quantities which are too small to be detected, or are already replaced by a more stable phase (smectite).

In conclusion, local acidification due to the oxidation of pyrite during cyclic humidity changes such as those regulated by seasons yields to the dissolution of illite layers in mixed-layer I-S. Dissolution of illite layers leads to the release of $\mathrm{K}$ into solution, which precipitates as jarosite during evaporation cycles (Fig. 12). Those phenomena are associated with calcite alteration by acid fluid and precipitation of gypsum and celestine.

The particular evolution of rock mineralogy in the EDZ zone is important when considering the general concept of nuclear waste storage. Thus, mineralogical changes at the surface of rocks may cause significant changes to the chemical features of the fluid in contact with the geological formation.

In the case of the Tournemire formation, the alteration of clay minerals is tenuous and localized, the expandable smectite layers being preserved. These changes are rather minor at Tournemire and appear insignificant for waste storage. However, repeated dehydration processes could lead to an important decrease in the swelling and sorption capacities of smectite in mixed-layer I-S. Moreover, other mineral transformations, such as sulphate formation might be important and cause modification of the fluid compositions. 


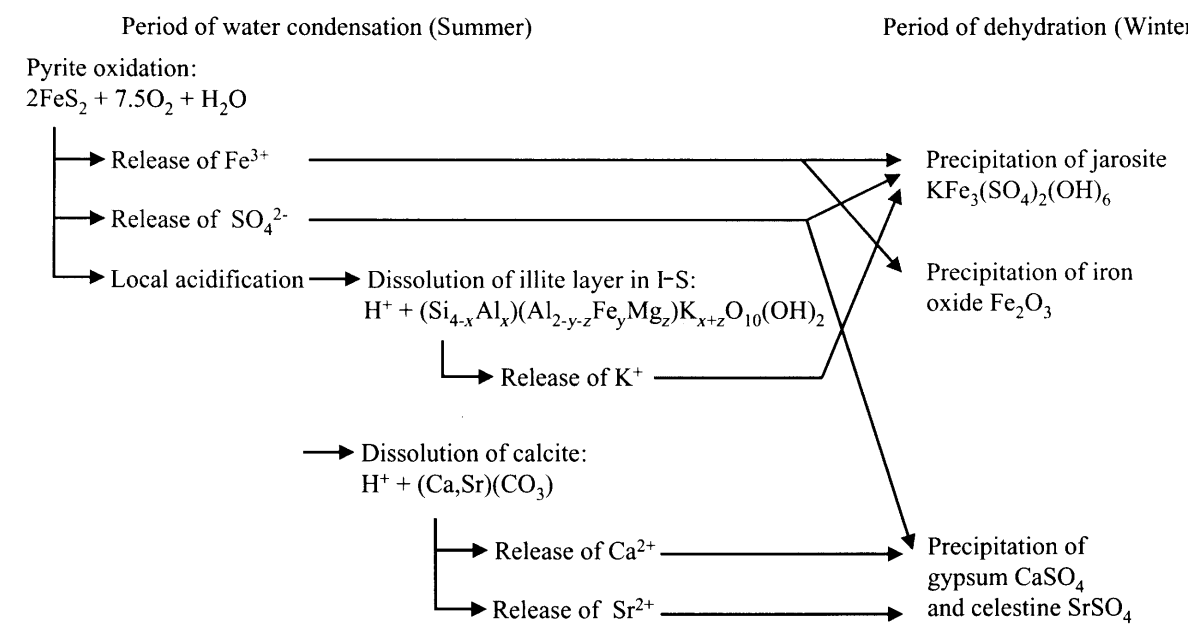

FIG. 12. Schematic representation of the oxidation mechanisms at the surface of blocks.

\section{ACKNOWLEDGMENTS}

This study was supported by IRSN (Institut de Radioprotection et de Sûreté Nucléaire), which provided access to the tunnel and samples. The assistance of G. Bruno and J. Cabrera is acknowledged.

\section{REFERENCES}

Aoudjit H., Elsass F., Righi D. \& Robert M. (1996) Mica weathering in acidic soils by analytical electron microscopy. Clay Minerals, 31, 319-332.

Bailey L.K. \& Peters E. (1976) Decomposition of pyrite in acids by pressure leaching and anodization: the case for an electrochemical mechanism. Canadian Metallurgical Quarterly, 15, 333-344.

Barbreau A. \& Boisson J.Y. (1993) Caractérisation d'une formation argileuse: synthèse des prinipaux résultats obtenus à partir du tunnel de Tournemire de Janvier 1992 à Juin 1993. CCE report nº1 EUR 15736 FR, ref. SERGD 93/22, France.

Bauer A. \& Berger G. (1998) Kaolinite and smectite dissolution rate in high molar $\mathrm{KOH}$ solutions at $35^{\circ} \mathrm{C}$ and $80^{\circ} \mathrm{C}$. Applied Geochemistry, 13, 905-916.

Blowes D.W. \& Jambor J.L. (1990) The pore-water geochemistry and the mineralogy of the vadose zone of sulfide tailings, Waite Amulet, Quebec, Canada. Applied Geochemistry, 5, 327-346.

Boisson J.Y. (1996) Caractérisation d'une formation argileuse. Caractérisations hydrogéologiques in situ des argilites $d u$ tunnel de Tournemire. Rapport d'avancement $\mathrm{n}^{\circ} 4 \mathrm{du}$ contrat CCE-CEA nFI2WCT91-0115-Réf.SERGD96/011, France.

Bonin B. (1998) Deep geological disposal in argillaceous formations: studies at the Tournemire test site.
Journal of Contaminant Hydrology, 35, 315-330.

Brookins D.G. (1984) Geochemical Aspects of Radioactive Waste Disposal. Springer Verlag, New York.

Cathelineau M., Guerci A., Ahamdach N. \& Cuney M. (1995) Smectite-goethite-Fe, U, Ca and Ba-sulfate assemblage resulting from bio-oxidation derived acid drainage in mine tailings: an analytical, experimental, and numerical approach. Pp. 647-649 in: Proceedings of the $3^{\text {rd }}$ biennal SGA Meeting (J. Pasava, B. Kribek \& K. Zak, editors). Balkema, Rotterdam, The Netherlands.

Charpentier D. (2001) Rôle de l'oxydation chimique et de l'acidification des eaux sur les propriétés minéralogiques et physico-chimiques de la formation argileuse de Tournemire. PhD thesis, Univ. Nancy I, France.

Charpentier D., Cathelineau M., Mosser-Ruck R. \& Bruno G. (2001) Evolution minéralogique des argilites en zones sous-saturées oxydées : exemple des parois du tunnel de Tournemire (Aveyron, France). Comptes Rendus de l'Académie des Sciences, 332, 601-607.

De Windt L., Cabrera J. \& Boisson J.Y. (1998) Hydrochemistry in an indurated argillaceous formation (Tournemire tunnel site, France). Pp. 145-148 in: Water Rock Interaction Proceedings (G.B. Arehart \& J.R. Hulston, editors). Balkema, Rotterdam, The Netherlands.

Galán E., Carretero M.I. \& Fernandez-Caliani J.C. (1999) Effects of acid mine drainage on clay minerals suspended in the Tinto River (Rio Tinto, Spain). An experimental approach. Clay Minerals, 34, 99-108.

Garrels R.M. \& Thompson M.E. (1960) Oxidation of pyrite by iron sulfate solutions. American Journal of 
Science, 258A, 57-67.

Gillot F., Righi D. \& Elsass F. (2000) Pedogenic smectites in podzols from central Finland: an analytical electron microscopy study. Clays and Clay Minerals, 48, 655-664.

Giraud A., Thouvenin G., Homand F. \& Didry O. (1999) Modélisation poroélastique de la dessaturation autour de cavités profondes. Pp. 375-380 in: $9^{\text {th }}$ International Congress on Rock Mechanics (G. Vouille \& P. Bérest, editors). Balkema, Rotterdam, The Netherlands.

Guillaume D., Pironon J. \& Ghanbaja J. (2001) Valence determination of iron in clays by electron energy loss spectroscopy. Berichte der Deutschen Mineralogischen Gesellshaft, Beih. z. European Journal of Mineralogy, 13, 70.

Harvey C.O. (1943) Some notes on the calculation of molecular formulae for glauconite. American Mineralogist, 28, 541-543.

Helgeson H.C. (1969) Thermodynamics of hydrothermal systems at elevated temperatures and pressures. American Journal of Science, 267, 724-804.

Higgo J.J.W. (1987) Clay as a barrier to radionuclide migration. Progress in Nuclear Energy, 19, 173-207.

Holtzapffel Y. (1985) Les minéraux argileux: Préparation, analyse diffractométrique et détermination. Société Géologique du Nord, 12, 136 pp.

Hower J. \& Mowatt T.C. (1966) The mineralogy of illites and mixed layer illite-montmorillonites. American Mineralogist, 51, 825-857.

Huang S.L., Speck R.C. \& Wang Z. (1995) The temperature effect on swelling of shales under cyclic wetting and drying. International Journal of Rock Mechanics and Mining Science and Geomechanics Abstracts, 32, 227-236.

Huertas F.J., Caballero E., Jimérez de Cisneros C., Huertas F. \& Linares J. (2001) Kinetics of montmorillonite dissolution in granitic solution. Applied Geochemistry, 16, 397-407.

Lalieux P., Thury M. \& Horseman S. (1996) Radioactive waste disposal in argillaceous media. NEA Newsletter, 34-36.

Madsen F.T. (1998) Clay mineralogical investigations related to nuclear waste disposal. Clay Minerals, 33, 109-129.

Meunier A. \& Velde B. (1989) Solid solutions in I/S mixed-layer minerals and illite. American Mineralogist, 24, 1106-1112.
Millot G. (1964) Géologie des Argiles. Masson, Paris.

Mustin C. (1992) Approche physico-chimique et modélisation de l'oxydation bactérienne de la pyrite par Thiobacillus ferrooxidans: rôle déterminant de la phase minérale. $\mathrm{PhD}$ thesis, Université Nancy I, France.

Panin V.V., Karavaiko G.I. \& Pol'kin S.I. (1985) Mechanism and kinetics of bacterial oxidation of suphide minerals. Pp. 197-215 in: Biogeotechnology of Metals (G.I. Karavaiko \& S.N. Groudev, editors). UNEP Moscow, USSR.

Pusch R. \& Karnland O. (1996) Physico/chemical stability of smectite clays. Engineering Geology. 41, 73-85.

Raz U. \& Peters T. (1989) The effect of iron and magnesium on the stability of illite and smectite. Pp. 569-572 in: Water-Rock Interaction Proceedings (D.L. Miles, editor). Balkema, The Netherlands.

Reynolds R.C. (1980) Interstratified clay minerals Pp. 249-303 in: Crystal Structures of Clay Minerals and their X-ray Identification (G.W. Brindley \& G. Brown, editors). Monograph 5, Mineralogical Society, London.

Sévèque J.L. (1986) Etude expérimentale de la dissolution des minéraux sulfurés en milieu oxydant: application à la prospection minière. $\mathrm{PhD}$ thesis, Université de Paris VI, France.

Teveldal S., Jorgensen P. \& Stuanes A.O. (1990) Longterm weathering of silicates in a sandy soil at Nordmoen, southern Norway. Clay Minerals, 25, 447-465.

Velde B. (1985) Clay Minerals. A Physico-chemical Explanation of their Occurrence. Elsevier, Amsterdam, Oxford, New York, Tokyo.

Velde B. \& Church T. (1999) Rapid clay transformations in Delaware salt marshes. Applied Geochemistry, 14, 559-568.

Wilson M.J. (1999) The origin and formation of clay minerals in soils: past, present and future perspectives. Clay Minerals, 34, 7-25.

Wolery T.J. \& Daveler S.A. (1992) EQ6, a computer program for reaction path modelling of aqueous geochemical systems: user's guide and documentation. Lawrence Livermore National Laboratory, University of California.

Zysset M. \& Schindler P.W. (1996) The proton promoted dissolution kinetics of K-montmorillonite. Geochimica et Cosmochimica Acta, 60, 921-931. 